\title{
ANIMASI MOTION GRAPHICS DINAMIKA LITOSFER PADA MATA PELAJARAN GEOGRAFI KELAS X SMA
}

\author{
Dea Amanda Amelia Revlinasari, I Nyoman Sudana Degeng, Agus Wedi \\ Jurusan Teknologi Pendidikan, Fakultas Ilmu Pendidikan, Universitas Negeri Malang \\ Jalan Semarang 5 Malang 65145 0341-574700 \\ Deaamanda13@gmail.com
}

\section{Article History}

Received: 20 Juli 2020, Accepted: 14 Desember 2020, Published: 28 Mei 2021

\begin{abstract}
Abstrak
Pengembangan motion graphic mampu menjadi alat pendukung berupa visual dengan menggambarkan isi dari materi Dinamika Litosfer. Siswa merasa lebih kesulitan dalam menggambarkan bentuk visual dari sebuah pembelajaran Dinamika Litosfer, sehingga membutuhkan sebuah tiruan. Tiruan jika dilakukan pada sebuah peralatan yang pada faktanya membutuhkan banyak biaya dan berbahaya. Maka penggunaan animasi beupa Motion Graphics mampu menjadi solusi yang bertujuan untuk dapat menangani keterbatasan antara ruang dan waktu dan menciptakan gairah belajar. Lee \& Owens, adalah metode yang digunakan dalam penelitian ini, karena metode tersebut memiliki langkah-langkah pengembangan sistematis dan mengutamakan dari hasil pengalaman penggunanya. Hasil review dari ahli materi dan ahli media menunjukkan nilai positif. Ahli media dan materi berpendapat secara menyeluruh materi sudah layak dan media sangat menarik. Animasi Motion Graphics mempunyai keunggulan yaitu mampu menciptakan minat dan motivasi belajar pebelajar, memperjelas hal abstrak dan menyampaikan gambaran lebih nyata
\end{abstract}

Keyword: lintas minat; multimedia drill and practic; kosakata

\begin{abstract}
Development of Motion Graphic animation can be a visual aid in describing the contents of the dynamics of the lithosphere. Students find it difficult to describe the visual form of lithosphere dynamics learning, so they need an imitation. Imitation when done on an actual equipment is costly and dangerous. So the use of motion graphics animation can be a solution so that students can handle the limitations between space and time and create a passion for learning. method used in this research is Lee \& Owens, because this method has systematic development steps and prioritizes the results of the user experience. The results of the reviews obtained from media experts and material experts show a positive value. Media and material experts think that overall the media is interesting and the material is appropriate. Motion graphics animation has the advantage of being able to make a motivation and interest in student learning, clarify an abstract thing and convey a more real picture.
\end{abstract}

Keyword: Put 3-5 your keywords here in Bahasa Indonesia; keywords separated by semicolon 


\section{PENDAHULUAN}

Kini proses pembelajaran menggunakan buku sebagai media untuk belajar masih berlangsung. Guru menjelaskan seluruh materi yang sudah ada dalam buku. Belajar hanya menggunakan buku terdapat beberapa kekurangan, diantaranya belajar dengan buku mampu meniadakan adanya interaksi terhadap pebelajar dengan pendidik. Dan dengan buku pendidik tidak dapat menunjukkan situasi sesungguh nya terhadap materi yang akan disampaikan. Melalui proses belajar mengajar seperti di atas, kurang optimal dalam mencapai tujuan pembelajaran. Perkembangan ilmu teknologi telah mengalami peningkatan cukup pesat mendorong upaya pembaharuan dalam berbagai aspek kehidupan. Begitupun yang dipaparkan oleh Septima \& Zulfa (2020) bahwa kemajuan teknologi sesuatu yang tidak bisa dihindari dalam kehidupan saat ini, karena kemajuan teknologi akan berjalan sesuai dengan kemajuan ilmu pengetahuan terutama pada bidang pendidikan. Yang dimana inovasi diperlukan untuk menciptakan pembelajaran menjadi berkesan untuk siswa, menyenangkan dan merangsang siswa belajar aktif dan mandiri dengan menggunakan suatu media pembelajaran yang dijadikan penghubung antara permasalahan guru dan permasalahan siswa.

Penggunaan media animasi pembelajaran motion graphics akan mempermudah dan membantu proses belajar mengajar. Siswa mampu belajar dengan menyerap dan melihat materi dengan utuh melalui media animasi. Dengan demikian, mempermudah guru untuk tidak harus menjelaskan pembelajaran secara berulang-ulang, sehingga proses pembelajaran dapat berlangsung jauh lebih berkesan, serta diterima oleh siswa dengan mudah. Dalam penelitian Yusuf (2017) menemukan bahwa animasi mampu meningkatkan pembelajaran dengan motivasi belajar siswa, sehingga menghasilkan peningkatan signifikan pada hasil belajar siswa. Hal ini didukung penelitian dari Sari (2013) yang menyatakan media animasi motion graphics mampu meningkatkan hasil dari belajar siswa. Sedangkan arti dari media animasi itu sendiri merupakan bentuk media yang sigunakan untuk interaksi antar guru dan siswa melalui gambar bergerak yang mirip dengan keadaan aslinya Harsono (2009). Lain lagi dengan penjelasan menurut Handani, Utami \& Kusmira (2016) fungsi dari motion graphics yaitu untuk menjelaskan topic, proses atau peristiwa secara visual kepada audiens melalui penggunaan animasi.

Menurut observasi di SMAN 1 Kota Batu, ditemukan fakta bahwa guru melaksanakan pembelajaran pada mata pelajaran Geografi materi dinamika litosfer cenderung terpaku dengan buku paket dan LKS. Sesuai dengan observasi awal dengan guru mata pelajaran Geografi SMAN 1 Batu Kota Batu yaitu Bapak Drs Bonari, S. Pd, mengungkapkan berbagai permasalahan sekolah menengah atas salah satunya yaitu mengenai pembelajaran teori yang kurang menarik perhatian siswa. Dalam masalah ini, penggunaan media sangatlah penting, seperti yang dilakukan Nurseto (2011) bahwa kegunaan media pembelajaran berfungsi sebagai alat mempercepat proses belajar dan dapat meningkatkan kualitas belajar agar lebih efektif.

Dapat diketahui bahwa mata pelajaran Geografi memiliki banyak materi yang menunjukkan illustrasi pada buku paket untuk menjadi acuan siswa seperti apa materi yang akan dijelaskan, khususnya dinamika litosfer tersebut. Hal itu sejalan dengan penelitian Sumarmi (2012) yang menyatakan bahwa pembelajaran geografi sulit dipaparkan jika hanya mengandalkan penjelasan secara teoritis di kelas, hal ini memerlukan menghubungkan dengan kondisi sebenarnya, oleh karena itu, untuk menghubungkan materi di kelas dengan lingkungan yang sebenarnya, penggunaan media sangat penting dan diperlukan. Materi litosfer dikelompokkan menjadi empat bagian, yaitu: batuan, struktur lapisan bumi, tenaga endogen, dan tenaga eksogen. Jenis topik materi melibatkan proses seperti pembentukan batuan beku, pergerakan lempeng tektonik pergerakan magma,, dan pelapukan batuan. Untuk menggambarkan materi tersebut, yang paling tepat dan mudah dimengerti oleh siswa dengan menggunakan media animasi motion graphics. Dengan motion graphics fenomena yang menarik dapat direpresentasikan sebagai fitur objek animasi yang memungkinkan direplikasi dan disimulasikan. 
Maka animasi motion graphics mampu menjadi pilihan untuk meningkatkan motivasi belajar siswa terhadap materi dinamika litosfer. Animasi motion graphics digunakan sebagai multimedia yang sesuai oleh siswa SMA mata pelajaran geografi. Dalam tujuan produksinya animasi motion graphics dapat digunakan sebagai media pembelajaran dalam dalam membantu memahami materi dan memotivasi belajar siswa yang masih rendah. maka perlu adanya pengembangan sebuah media pembelajaran agar pembelajaran dapat disampaikan dengan menarik. Dalam pembelajaran di kelas, bahan ajar yang sering digunakan adalah sebuah modul buku dan buku paket. Bahan ajar animasi dipillih karena kelebihan yang dimiliki tidak terdapat pada bahan ajar jenis lainnya. Kelebihan pertama, bahan ajar animasi terdapat perpaduan antara media bergerak dengan teks. Kedua, Perpaduan tersebut memiliki manfaat untuk siswa karena bahan ajar di tunjukkan secara utuh dengan berbagai kombinasi media yang jauh lebih lengkap daripada bahan ajar cetak. Sehingga mempermudah siswa dalam pemahaman materi karena media bergerak mampu mengillustrasikan layaknya lingkungan sebenarnya.

Dalam penelitian ini produk yang dihasilkan berupa animasi motion graphics tentang dinamika Litosfer. Selain itu penyajian materi dibuat dengan sedetail mungkin dengan menggunakan berbagai macam animasi, gambar, audio serta bahasa yang komunikatif yang dapat memudahkan siswa dalam memahami materi sesuai dengan karakteristik belajar siswa. Dengan demikian media animasi motion graphics diharapkan mampu memudahkan proses penyampaian materi kepada siswa dan mampu menarik perhatian siswa dalam pembelajaran.

\section{METODE}

Penelitian dan pengembangan menghasilkan animasi motion graphic untuk siswa SMAN 1 Kota Batu kelas X IPS. Model pengembangan dari Lee \& Owens (2004) digunakan untuk mengembangkan produk. Metode tersebut dipilih karena memiliki prosedur yang sesuai dalam pengembangan multimedia pembelajaran dengan setiap langkahnya tersusun secara sistematis dan jelas khusus nya mengutamakan hasil dari pengalaman penggunaanya. Metode tersebut menyediakan desain intruksional dalam mengembangkan angket serta mencantumkan respon dari pengalaman pengguna multimedia yang digunakan. Sehingga, produk yang dihasilkan layak dan sesuai dengan kebutuhan untuk digunakan. Dalam model pengembangan Lee \& Owens (2004), memiliki 5 tahapan yang perlu dilakukan, dimulai dari tahap analisis yang terbagi atas tahap assessment/analisis yang terdiri dari dua tahap Need Assessment dan Front-End Analysis, tahap desain, tahap pengembangan, implementasi, evaluasi. Namun penelitian hanya dilakaukan pada tahap satu hingga tiga karena multimedia pembelajaran hanya mengukur tingkat kelayakan.

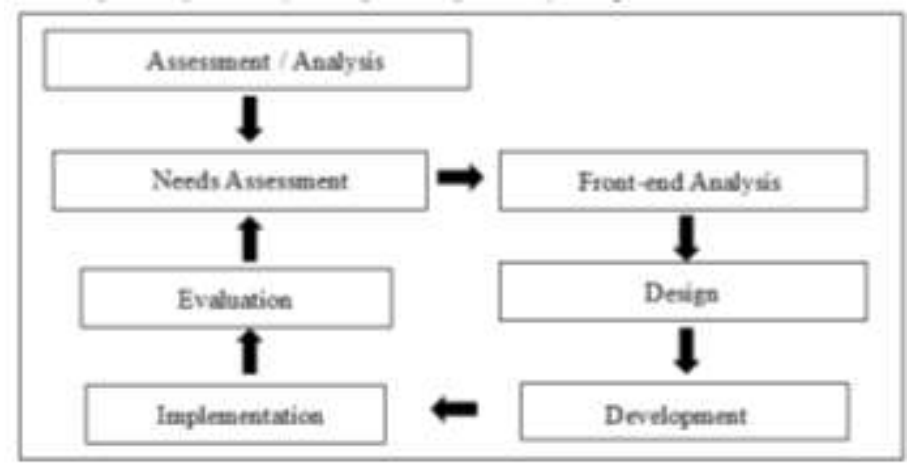

\section{Gambar 1. Prosedur pengembangan Model Lee \& Owens (2004)}

Tahap pertama yaitu assessment/analisis terdiri dari Need Assessment yaitu analisis kebutuhan dilakukan dengan cara observasi langsung untuk mengetahui keadaan sekolah. Sedangkan Front-End Analysis merupakan mendapat informasi yang akurat dan detail untuk media yang dikembangkan. Tahap 
ini terdiri dari audience analysis, media analysis, situation analysis, taks analysis, critical analysis, objective analysis, issue analysis, technology analysis, extand-data analysis dan cost analysis.

Pada tahap kedua ialah desain. Desain disini melakukan perencanaan produk yang akan dibuat, seperti membuat struktur konten atau storyboard. Desain interface serta komponen lain yang perlu disusun seperti, audio narasi, tujuan pembelajaran hingga gerakan tiap slide animasi, karena struktur komponen penting untuk pembuatan media animasi.

Pada tahap ketiga yaitu pengembangan. pengembangan animasi motion graphics dikembangkan melalui beberapa aplikasi, salah satunya yakni Adobe after effects. Adobe after effects merupakan aplikasi motion graphics dan visual effects yang dibuat oleh Adobe system Inc dan perangkat lainnya. Software ini merupakan aplikasi animasi dan visual effects banyak digunakan tidak hanya untuk membuat animasi motion graphics namun juga profesional di bidang video Winastwan (2006). Tujuannya adalah produk media digital yang berupa animasi motion graphics. Pengembangan instrumen juga dilakukan untuk menguji kelayakan media pembelajaran pada ahli media dan materi.

Sedangkan ada tahap implementasi dan evaluasi tidak dilakukan dengan alasan multimedia pembelajaran masih dalam uji coba dalam kesiapan teknologi dalam pengembangan produk. Teknik analisis data menurut Lee \& Owens (2004), menggunakan rating scale yang dipengaruhi oleh total data dan respon yang didapat setiap pernyataan pada angket. Berikut adalah rating scale penilaian skor yang diperoleh pada angket: Sangat Setuju bernilai (4), Setuju bernilai (3), Tidak setuju bernilai (2), Sangat tidak setuju bernilai (1).

\section{HASIL}

\section{Need Assesment}

Need Assessment atau analisis kebutuhan dilakukan dengan cara wawancara dan observasi langsung untuk mengetahui keadaan sekolah. Hal ini bertujuan untuk menentukan arah pengembangan dan menetapkan hal yang dibutuhkan menyesuaikan dengan permasalahan yang ada di sekolah. Animation Motion Graphics ini perlu untuk pembelajaran di dalam kelas mengingat permasalahan yang terjadi berdasarkan hasil observasi langsung di sekolah., yaitu pembelajaran hanya menggunakan buku atau gambar saja, sedangkan pemberian materi selalu mengandalkan pembahasan verbal saja, yang menyebabkan siswa cepat bosan, dan kurang termotivasi

\section{Front-end Analysis}

Tahapan ini bertujuan untuk mendapatkan informasi secara detail tentang produk/media yang akan dikembangkan. Kegiatan dari tahap ini ialah analisis terhadap karakteristik siswa, situasi dan kondisi serta ketersediaan dara prasarana di SMAN 1 Batu. Hal ini berfungsi untuk mengetahui gambaran terkait pelaksanaan kegiatan selanjutnya agar dapat menentukan media pembelajaran yang tepat sesuai tujuan pembelajaran yang akan dilaksanakan.

\section{Design}

Kegiatan pada tahap desain yaitu melakukan perencanaan dalam mengembangkan produk animasi motion graphics. Pada tahap desain ini akan dilakukan kegiatan seperti produk yang akan dibuat, seperti membuat struktur konten. Desain interface serta komponen lain yang perlu direncanakan seperti, audio pengucapan, tujuan pembelajaran hingga pembuatan animasi-animasi, karena struktur konten pada tahap desain sangat penting dalam pembuatan media itu sendiri.

\section{Development}

Tahap ketiga ialah pengembangan, dimana kegiatan ini memproduksi Animasi Motion Graphics pembelajaran dengan menggunakan format $\mathrm{mp} 4$, mengembangkan elemen-elemen yang telah disusun, dilanjutkan dengan penilaian media kepada para ahli, yaitu ahli media dan ahli materi. Setelah di review dan terdapat revisi, maka media segera diperbaiki sesuai saran dari para ahli hingga mendapat penilaian media yang layak digunakan kepada siswa. Software yang digunakan untuk mengembangkan produk 
adalah Adobe Illustraror CC 2017, Adobe Premier Pro CC 2015, Adobe After Effect CC 2017. Berikut adalah hasil yang diperoleh dari review angket dari ahli media dan ahli materi pada animasi motion graphic. Setelah produk selesai dibuat, kemudian tahap berikutnya adalah tahap review dan uji coba oleh subyek penelitian.

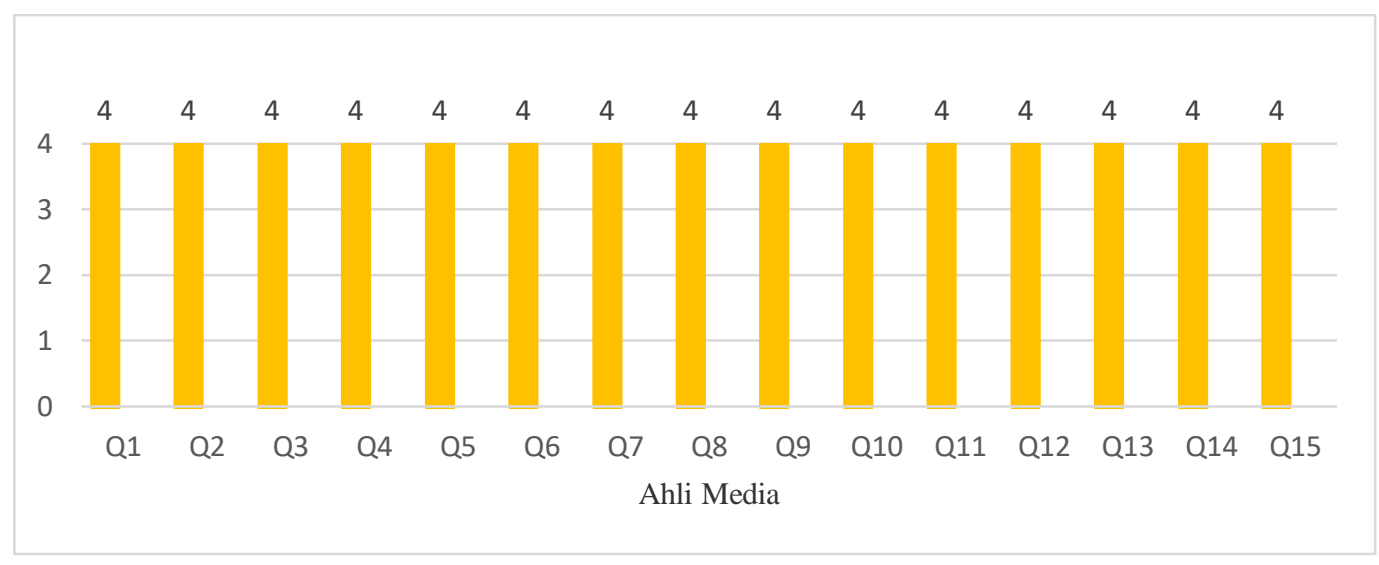

Gambar 2 . Diagram Hasil Review Ahli Media

Berdasarkan gambar 2 hasil review ahli media dari penyajian 15 pernyataan diatas terdapat 15 pernyataan mendapat nilai 4 . Dari nilai yang didapatkan animasi motion graphics bernilai positif dan layak untuk digunakan. Ahli media juga memberikan respon bahwa desain dan tampilan animasi motion graphics jika secara umum sudah bagus.

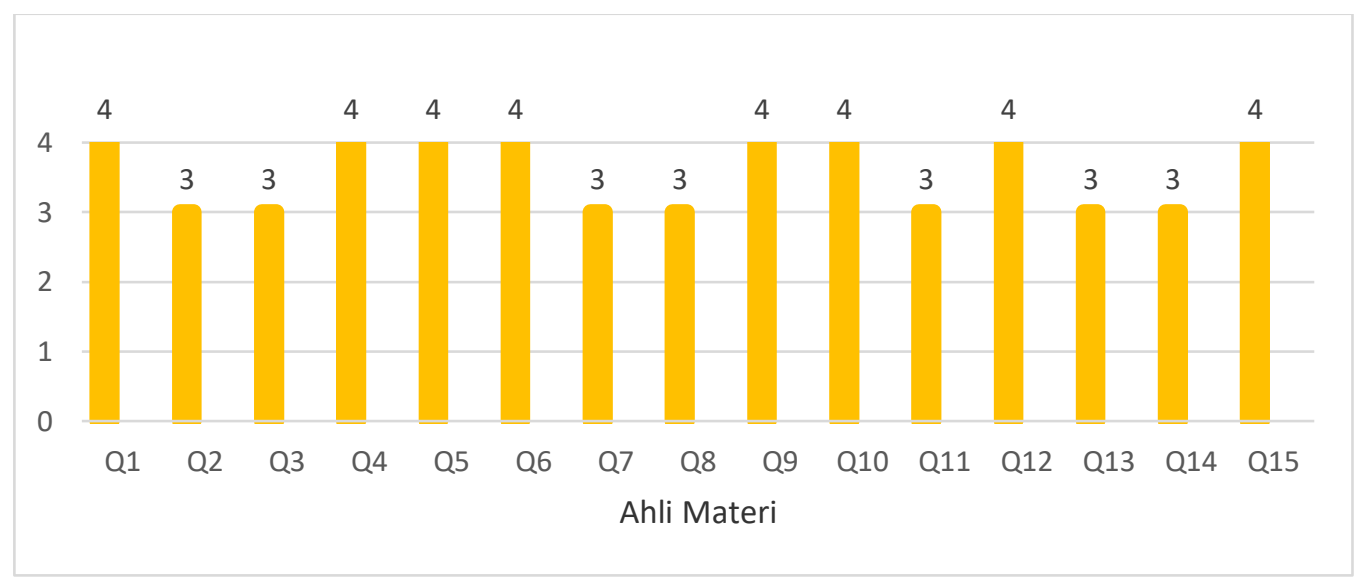

\section{Gambar 3. Diagram Hasil Review Ahli Materi}

Berdasarkan gambar 3 hasil review ahli materi dari penyajian 15 pernyataan diatas terdapat 8 pernyataan mendapat nilai 4, 6 pernyataan mendapat nilai 3. Sehingga animasi motion graphics bernilai positif dan layak untuk digunakan. Ahli materi juga memberikan respon bahwa materi supaya lebih detail dapat melihat buku berjudul ilmu bumi penulis tarbuck terbitan erlangga.

\section{PEMBAHASAN}

\section{Need Assessment}

Need Assessment atau Analisis kebutuhan dilakuan dengan melakukan observasi. Dari Hasil observasi di SMAN 1 Batu mendapatkan hasil yaitu saat mejelaskan materi dinamika litosfer mata pelajaran Geografi. SMAN 1 Batu tidak begitu tertarik menggunakan verbal saja dan hanya bisa membayangkan bagaimana proses Litosfer itu terjadi. Siswa belajar hanya menggunakan buku maupun gambar yang menyebabkan siswa cepat bosan, dan kurang termotivasi. Yang mempersulit mereka dalam meresap informasi yang akan disampaikan oleh pengajar. Terlihat dari, respon siswa yang cenderung mengantuk saat proses pembelajaran. Karena guru hanya menggunakan buku sebagai alat bantu dalam menyampaikan materi yang berisi gambar-gambar proses terjadinya litosfer. Maka animasi motion 
graphics perlu digunakan dalam pembelajaran, khususnya siswa SMA IPS yang mengalami kesulitan dalam memahami materi.

\section{Front-end Analysis}

Front-end analysis merupakan sebuah teknik dalam pengumpulan data dan memiliki tujuan untuk mendapatkan informasi lebih detail untuk media yang dikembangkan. Tahapan ini menganalisis karakteristik pada siswa, serta fasilitas hingga keadaan di SMAN 1 Kota Batu agar diperoleh gambaran informasi untuk pengembangan yang dilakukan. Dalam ungkapan Isnanto (2004) menyatakan bahwa orang dapat mengingat gambaran yang dilihat sebanyak $20 \%$ dan $30 \%$ suara dari yang didengar dan akan mengingat yang dilihat sebanyak 50\% secara sekaligus dengan mendengar dan $80 \%$ dari apa yang didengar dan dilihat, yang dilakukan sekaligus. Dengan demikian, media animasi menjadi perangkat ampuh untuk proses pengajaran dan pendidikan. Adapun manfaat yang didapat menurut Sakti (2013) animasi menjadikan pilihan yang tepat untuk menunjang proses belajar lebih menyenangkan dan menarik bagi siswa serta dapat mempermudah pemahaman siswa dan memberikan motivasi terhadap pelajaran yang akan dipelajari. Fasilitas di SMAN 1 Batu Kota Batu telah mendukung penggunaan media pembelajaran motion graphic. Berupa LCD Proyektor, dan Speaker. Media Pembelajaran motion graphic ini sangat fleksibel karena memiliki format .mp4 sehingga dapat ditayangkan pada smartphone maupun laptop. Sehingga akses siwsa dalam menggunakan media pembelajaran dapat terfalititasi.

\section{Design}

Produk yang dihasilkan berupa animasi Motion Graphics yang dapat dioperasikan di laptop/computer dan bisa juga dapat menggunakan smartphone. Pembuatan animasi yang menarik akan memudahkan siswa dalam menangkap materi pelajaran lebih cepat, hal itu dikarenakan bahwa hal utama yang dilihat dari siswa adalah penampilan terlebih dahulu, jika awal tampilan sudah menarik seperti adanya animasi motion graphics, maka siswa akan lebih mudah memahami pelajaran yang akan disampaikan. Hal itu sejalan dalam penjabaran penelitian Purwanti \& Haryanto (2015) mengatakan bahwa media yang dikembangkan melalui motion graphics mampu membangun suasana kelas menjadi lebih menyenangkan dan mudah dipahami dengan mudah. Selain itu nilai pre test dan post test siswa mengalami peningkatan dengan kategori sedang yang artinya terdapat perubahan terhadap cara belajar siswa setelah menggunakan motion graphics. Lain halnya penelitian yang dihasilkan Aryani \& Everlin (2020) penggunaan video motion graphics sangat penting guna menyampaikan informasi yang baik dan edukatif serta penjelasan akan lebih mudah diterima oleh target audiens. Begitu juga penelitian yang disampaikan Saputra \& Shofa (2015) memaparkan bahwa penggunaan media animasi mampu menjelaskan suatu konsep atau proses yang sukar dijelaskan dengan media lain, animasi juga memiliki daya tarik estetika, sehingga tampilan yang menarik dan memotivasi mampu membangun minat belajar siswa.

\section{Development}

Tahap ini merupakan tahap yang dikembangkan yaitu file berupa animasi motion graphics. Dalam mengembangkan animasi motion graphics, dengan menggunakan software yaitu: Adobe Illustraror CC 2017, Adobe Premier Pro CC 2015, Adobe After Effect CC 2017. 


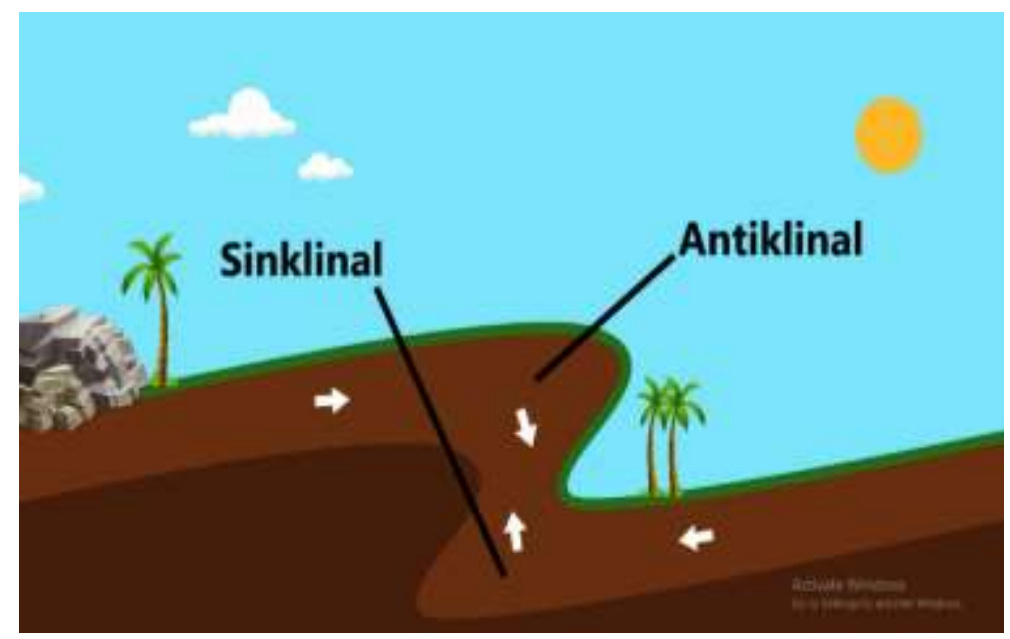

Gambar 4. Tampilan Pembahasan Materi

Berdasarkan gambar 4 tampilan pembahasan, yang menjelaskan berbagai pokok pembahasan yang berkaitan dengan dinamika litosfer. Animasi motion graphics dipaparkan sesuai dengan pembahasan dan animasi yang ditampilkan. Suara narasi yang juga mampu memperjelas maksud yang disampaikan, sehingga siswa mampu memahami materi. Mempermudah belajar siswa melalui penyajian materi yang bervariasi. Animasi Motion Graphic dapat diambil dengan berbagai jenis dan gaya. Motion Graphic menggunakan design yang sederhana, gambar yang dihasilkan juga terlihat nyata dan fleksibel sehingga informasi yang akan disampaikan tidak terlalu rumit dan jadi lebih mudah diingat.

\section{Review Ahli Media dan Materi}

Berdasarkan hasil review motion graphics oleh para ahli, bahwa multimedia yang dikembangkan secara keseluruhan sudah bagus dengan konten yang sesuai dengan materi. Sesuai dengan ungkapan Kusumadewi \& Rati (2020) Perlu adanya inovasi yang berbeda dari biasanya agar pembelajaran dapat menggugah semangat belajarnya siswa. Selain itu media pembelajaran yang baik dan efektif harus dikembangkan secara adaptif sesuai dengan keunikan gaya belajar para pengguna Surahman, Wedi, Soepriyanto, \& Setyosari (2018). Hal itu dapat di buktikan melalui hasil review ahli media didapatkan dari penyajian 15 pernyataan diatas terdapat 15 pernyataan mendapat nilai 4 . Dari nilai yang didapatkan motion graphics bernilai positif dan layak untuk digunakan. Ahli media juga memberikan respon bahwa desain dan tampilan animasi motion graphics jika secara umum sudah bagus. Sedangkan review dari ahli dari penyajian 15 pernyataan diatas terdapat 8 pernyataan mendapat nilai 4 , 6 pernyataan mendapat nilai 3. Sehingga animasi motion graphics bernilai positif dan layak untuk digunakan. Ahli materi juga memberikan respon bahwa materi ditambah supaya lebih detail dapat melihat buku berjudul ilmu bumi penulis tarbuck terbitan erlangga.

Penelitian mengenai motion graphics sebelumnya juga telah dilakukan oleh Efendi (2020), mengembangkan multimedia pembelajaran berupa media animasi motion graphics pada mata pelajaran IPA di SDN Pandanrejo 1 Kabupaten Malang. Hasil review ahli media, keseluruhan hasil diperoleh skor 42 dengan persentase $87,5 \%$. Berdasarkan kriteria dapat simpulkan media yang sudah dikembangkan termasuk kategori layak digunakan dalam pembelajaran. Hasil review ahli materi, keseluruhan hasil data diperoleh skor 40 dengan persentase 83,3\%. Berdasarkan kriteria dapat disimpulkan media yang sudah dikembangkan termasuk kategori layak digunakan dalam pembelajaran. Respon dari para ahli adalah tampilan dan format penyajian secara keseluruhan menarik. Sedangkan respon siswa yaitu, tampilan yang menarik menjadikan siswa lebih mudah memahami materi Litosfer yang telah dipelajari.

Sama halnya dalam penelitian yang dilakukan oleh Paik \& Schraw (2013) mengatakan bahwa media pembelajaran animasi motion graphics lebih berpotensi menarik siswa daripada menggunakan buku, karena mampu menyajikan tampilan visual dari berbagai jenis fenomena dan informasi abstrak 
yang mengarah kepada proses pembelajaran dan hasil pembelajaran yang meningkat secara signifikan. menemukan bahwa hasil uji coba lapangan dengan menggunakan media animasi motion graphics pembelajaran menghasilkan peningkatan hasil belajar dari pada saat menggunakan media buku. Dalam penelitian Kwasu (2015) mengatakan bahwa penerapan efektifitas dalam menggunaan media animasi merupakan alat yang dapat diandalkan untuk proses belajar mengajar, tampilan media animasi dapat memanipulasi materi benda mati menjadi lebih hidup,dengan demikian animasi dapat mewujudkan pembelajaran menjadi menyenangkan. Begitu juga penelitian yang dilakukan Amali, Zees, \& Suhada, (2020) memaparkan bahwa video animasi motion graphic dapat digunakan sebagai media alternatif pelajaran, dimana proses pembelajaran tersebut dikategorikan sangat baik karena hasil dan prestasi yang diperoleh mendapatkan nilai diatas rata-rata.

Berikut penelitian yang sama seperti sebelumnya dilakukan oleh Madar \& Hashim (2011) juga memaparkan bahwa animasi grafis mampu meningkatkan secara efektif prestasi akademik siswa untuk mata pelajaran sistem elektronik 1 di politeknik KPTM. Sama halnya pada penelitian Berk (2009) menjelaskan bahwa belajar menggunakan media bergambar (audio dan visual ) akan lebih baik dari pada belajar kondisi verbal (audio). Selain itu pada penelitian Shir \& Asadollahi (2014) dengan penggunaan media motion graphics dapat membantu komunikasi secara profesional dengan memanfaatkan teknik baru yang dapat membuat suasana lebih efektif karena media tersebut dapat mempengaruhi pikiran audiens. Pada penelitian Sukiyasa \& Sukoco (2013) telah memparkan bahwa penggunaan media animasi dapat meningkatkan motivasi dan hasil belajar siswa kelas X TKR SMK Negeri 1 Seyegan pada materi sistem kelistrikan otomatif dengan pencapaian yang lebih tinggi dibanding dengan penggunaan media powerpoint. Mayoritas hasil pengalaman dari penelitian sebelumnya yaitu multimedia pembelajaran bagus digunakan untuk membantu belajar siswa. Media dengan menggunakan motion graphics mampu menyampaikan konsep pembelajaran disertai dengan teks, grafis, dan warna, sehingga mampu menjadi sarana untuk menarik perhatian sekaligus memberikan pemahaman lebih kepada pebelajar atas materi yang disampaikan.

\section{SIMPULAN}

Proses pembelajaran yang hanya menggunakan buku sebagai media untuk belajar mampu membuat siswa kesulitan dalam memahami materi pembelajaran. Maka siswa memerlukan media pembelajaran yang bertujuan untuk memepermudah proses belajar. Pengembangan media animasi motion graphics merupakan pilihan yang tepat untuk meningkatkan keinginan belajar juga pemahaman siswa terhadap pelajaran IPS materi dinamika litosfer. Media animasi motion graphics dapat menjadi solusi dalam meringankan dan mempermudah guru dalam menyampaikan materi, juga membantu siswa untuk memahami materi dengan tanggap. Hal tersebut menunjukkan bahwa siswa lebih tertarik menggunakan inovasi media animasi motion graphics daripada hanya menggunakan buku atau LKS.

Media pembelajaran berupa animasi motion graphics dapat meningkatkan minat siswa terhadap suatu mata pelajaran, yang berimplikasi pada penambahan atau peningkatan pengetahuan siswa terhadap mata pelajaran tersebut dan nilai siswa pada mata pelajaran tersebut. Fungsi dari motion graphics yaitu untuk menjelaskan topik, proses, atau peristiwa secara visual kepada audiens melalui penggunaan animasi. Dengan motion graphics fenomena yang menarik dapat direpresentasikan sebagai fitur objek animasi yang memungkinkan direplikasi dan disimulasikan. Konten yang disajikan berupa animasi dan suara narasi untuk mempermudah siswa dalam pehaman materi. Dan didapatkan riview media dari para ahli yaitu animasi motion graphics layak digunakan. Dapat disimpulkan bahwa media pembelajaran khususnya media animasi motion graphics dalam proses pembelajaran mampu memberikan hasil yang positif belajar siswa. Selain itu, penggunaan media animasi motion graphics dapat menjembatani siswa dalam menerima pelajaran dan guru dalam menyampaikan pembelajaran yang menumbuhkan ataupun meningkatkan motivasi belajar siswa

\section{DAFTAR RUJUKAN}


Amali, L. N., Zees, N., \& Suhada, S. (2020). Motion graphic animation video as alternative learning media. Jambura Journal of Informatics, 2(1), 23-30.

Aryani, N., \& Everlin, S. (2020). Perancangan motion graphic tentang pentingnya semua imunisasi bagi anak. Jurnal Titik Imaji, 2(2).

Berk, R. A. (2009). Multimedia teaching with video clips: TV, movies, YouTube, and mtvU in the college classroom. International Journal of Technology in Teaching \& Learning, 5(1).1-21

Efendi, Y. A., Adi, E. P., \& Sulthoni, S. (2020). Pengembangan Media Video Animasi Motion Graphics pada Mata Pelajaran IPA Di SDN Pandanrejo 1 Kabupaten Malang. JINOTEP (Jurnal Inovasi dan Teknologi Pembelajaran): Kajian dan Riset Dalam Teknologi Pembelajaran, 6(2), 97-102

Handani, S. W., Utami, S., \& Kusmira, D. (2017). Visualisasi Pencemaran Air Menggunakan Media Animasi Infografis. Jurnal Telematika, 10(1), 147-162.

Harsono, B. (2009). Perbedaan hasil belajar antara metode ceramah konvensional dengan ceramah berbantuan media animasi pada pembelajaran kompetensi perakitan dan pemasangan sistem rem. Jurnal Pendidikan Teknik Mesin, 9(2).

Isnanto, R. R. (2004). Aplikasi Teknologi Multimedia pada Bidang Pendidikan Sains dan Teknologi. In Seminar Nasional Aplikasi Teknologi Informasi (SNATI).

Kesumadewi, D. A., Agung, A. A. G., \& Rati, N. W. (2020). Model Pembelajaran CIRC Berbantuan Media Cerita Bergambar Meningkatkan Hasil Belajar Bahasa Indonesia Siswa SD. MIMBAR PGSD Undiksha, 8(2), 303-314.

Kwasu, I. A. (2015). Effectiveness of Animated Instructional Resource for Learning Facilitation among Secondary School Student in Bauchi Nigeria. Journal of Education and Practice, 6(21), 113-120.

Lee, W. W., \& Owens, D. L. (2004). Multimedia-based instructional design: computer-based training, web-based training, distance broadcast training, performance-based solutions. John Wiley \& Sons

Madar, A. R., \& Hashim, M. N. (2011). Effectiveness of using graphic animation courseware for students with different cognitive styles and spatial visual abilities. Journal of Technical Education and Training, 3(1).

MARETHA SARI, E. G. A. (2018). Pengembangan Media Video Animasi Motion Graphic Pada Mata Pelajaran Sejarah Materi Pokok Indonesia Zaman Praaksara Di Sma Negeri 4 Sidoarjo. Jurnal Mahasiswa Teknologi Pendidikan, 9(1).

Muhammad, H., Murtinugraha, R. E., \& Musalamah, S. (2020). Pengembangan Media Pembelajaran ELearning Berbasis Moodle Pada Mata Kuliah Metodologi Penelitian. Jurnal Pensil: Pendidikan Teknik Sipil, 9(1), 54-60. Kim, J. H., Lim, S. A., \& Choi, H. H. (2014). Promotional Video Production which fused The Motion Graphics and Color Marketing. Life Science Journal, 11(7s)

Nurseto, T. (2011). Membuat media pembelajaran yang menarik. Jurnal Ekonomi dan pendidikan, 8(1).

Paik, E. S., \& Schraw, G. (2013). Learning with animation and illusions of understanding. Journal of Educational Psychology, 105(2), 278-289.

Purwanti, A., \& Haryanto, H. (2015). Pengembangan motion graphic pembelajaran mata pelajaran pendidikan kewarganegaraan kelas I sekolah dasar. Jurnal Inovasi Teknologi Pendidikan, 2(2), 190-200.

Sakti, I. (2013). Pengaruh media animasi fisika dalam model pembelajaran langsung (direct instruction) terhadap minat belajar dan pemahaman konsep fisika siswa di SMA Negeri Kota Bengkulu. Prosiding SEMIRATA 2013, 1(1). 
Saputra, H. J., \& Shofa, V. M. (2015, March). Keefektifan Media Video Animasi Terhadap Kemampuan Menulis Karangan Narasi dan Hasil Belajar Siswa Kelas IV SD Negeri Bandungrejo 02 Mranggen. In SEMINAR NASIONAL PGSD 2015.

Septima, R., \& Zulfa, I. (2020). Pelatihan Ilmu Teknologi Komputer Dalam Meningkatkan Kemampuan Administrasi Perangkat Desa Tan Saril. JPKMI (Jurnal Pengabdian Kepada Masyarakat Indonesia), 1(1), 1-7.

Shir, M. F. D., \& Asadollahi, M. O. S. T. A. F. A. (2014). The role of motion graphics in visual communication. Indian Journal of Scientific Research, 7(1), 820-824.

Sukiyasa, K., \& Sukoco, S. (2013). Pengaruh media animasi terhadap hasil belajar dan motivasi belajar siswa materi sistem kelistrikan otomotif. Jurnal Pendidikan Vokasi, 3(1).

Sumarmi. 2012. Model-Model Pembelajaran Geografi. Malang: Aditya Media Publishing

Surahman, E., Wedi, A., Soepriyanto, Y., \& Setyosari, P. (2018, December). Design of Peer Collaborative Authentic Assessment Model Based on Group Project Based Learning to Train Higher Order Thinking Skills of Students. In International Conference on Education and Technology (ICET 2018). Atlantis Press.

Umam, N. C. (2016). Perancangan Motion Graphic Pengenalan Batik Gemawang Khas Kabupaten Semarang (Doctoral dissertation) Institut Seni Indonesia Yogyakarta, Yogyakarta, Indonesia.

Winastwan, G. (2006). Step by step Motion Graphics \& visual effects menggunakan Adobe after effects 6.0. Surabaya: Penerbit Andi.

Yusuf, M. M., Amin, M., \& Nugrahaningsih. (2017). Developing of instructional media-based animation video on enzyme and metabolism material in senior high school. Jurnal Pendidikan Biologi Indonesia, 3(3), 254-257. 